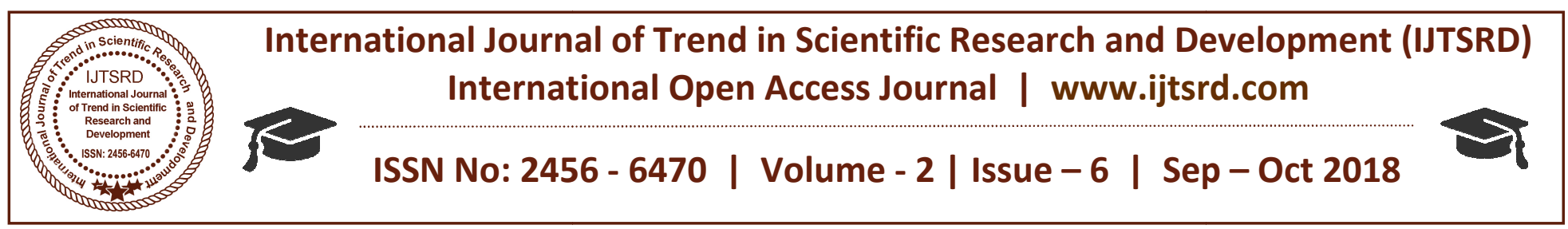

\title{
Globalization and its Impact on Human Resource Management: An Overview
}

\author{
V. Sriramulu \\ Research Scholar in Management, Bharathiar University, \\ Coimbatore, Tamil Nadu, India
}

\begin{abstract}
The roles and responsibilities of Human Resources departments are transforming as the modern business faces pressures of globalization. The global supply of talent is short of its long-term demand, and the gap is a challenge for employers everywhere. The shortage between the demand and supply of talent is likely to continue to increase, notably for high skilled workers and for the next generation of business executives. Now organizations need to place greater emphasis on attracting human capital rather than financial capital. Global staffing and management of a workforce diverse in culture and language skills and dispersed in different nations are the key goals of global human resources. Only those multinational enterprises willing to adapt their human resource practices to the changing global labor market conditions will be able to attract and retain high performing employees. Companies with the ability to foresee their business needs and their workforce needs - especially for high skills - will gain the decisive competitive advantage.
\end{abstract}

Keywords: Human Resource Management, Globalization, Data Analytics, Data Warehouse, Online Analytical Processing, Data Mining, Key Performance Indicators, Dashboards, Scorecards.

\section{INTRODUCTION}

Human Resources departments are transforming as the modern business faces numerous and complex challenges, and exploit opportunities. The transformation of human resources today is a direct call of the rapid changes within businesses due to factors such as globalization. In the global competition within the flat and connected new world, decision making in organizations has become increasingly intricate and convoluted. The new global world has widened the talent pool for excellent and marginal workers, and for permanent and fluid workers. An organization's talent can be a source for a sustained competitive advantage and can affect important organizational outcomes such as survival, profitability, customer satisfaction level, and employee performance (Pfeffer, 1994; Prahalad, 1983). Human resources need to take advantage of technology and data analytics to build a global human resource information system that collects and stores data from various sources. The system will help to analyze the data to provide business insights, predict future needs and develop strategies to fill those needs. Companies with the ability to foresee and sustainably manage their workforce needs - especially for high skills - will gain the decisive competitive advantage.

The global supply of talent is short of its longterm demand, and the gap is a challenge for employers everywhere. The shortage between the demand and supply of talent is likely to continue to increase, notably for highly-skilled workers and for the next generation of middle and senior leaders. Most emerging nations with large populations, including Brazil, Russia, India, and China, may not be able to sustain a net surplus workforce with the right skills for much longer. Now, more than ever, organizations need to place greater emphasis on attracting human capital rather than financial capital. Because capital is broadly available from investors and lenders, and innovations can be duplicated relatively easily and quickly, effective human resource management is the best way to differentiate one company from another. Global staffing and global leadership development are the two components of global human resources with the greatest potential for powerful leverage for global firms (Pucik, 1996). Only the multinationals that will be willing to adapt their human resource practices to 
the changing global labor market conditions will be able to attract, develop and retain the right talent, and will likely succeed in the global competition.

\section{Impact of Globalization on HRM: Diversity Recruitment}

With the rise of globalization, companies of all sizes are now interacting with customers and stakeholders from diverse cultures, languages and social backgrounds. In response, many human resources managers seek to hire employees from equally diverse backgrounds. Companies engaging in this diversity recruitment recognize the value of having people on staff that their customers can relate to, and they know that having a team of diverse people contributes to the range of ideas and influences within the organization.

\section{Push for Professional Development}

A further effect of globalization on HR management is a push for professional development. Professional development is concerned with providing employees opportunities to achieve their career-related goals. Some organizations provide resources for their employees to earn a university degree, others send their employees to conferences or networking events and training days. Professional development is important to globalization because it creates a winwin situation. The employees feel as though the organization is concerned with providing a range of skills and competencies for their employees. Likewise, the organization benefits from the added skills and connections that the employees who take advantage of professional development programs acquire.

\section{Greater Emphasis on Training}

Similar to professional development, a greater emphasis on training has resulted because of globalization in human resources management. Training, however, tends to be focused on the needs and professional competencies of groups of employees within the organization. The company might, for instance, host language classes to give its call center staff an edge in telephone sales. It might also teach its employees how to use a new global software platform. This emphasis on training seeks to give the company a competitive edge in the global marketplace by honing the employees' diversity emphasis.

\section{Management of Laws across Jurisdictions}

A final effect of globalization on human resources management is the need for businesses to understand and apply the laws of many different jurisdictions to the particular business. The federal government sets out a number of tax and labor laws that businesses operating in the United States must comply with, but there may also be local and regional laws that apply to companies that operate in different states or different countries. Selling products in Europe, for example, might mean that a company has to impose a ValueAdded Tax on its goods. Hiring employees at branch locations in different locations might change the requirements on minimum wage, tax allowances or working hours. Understanding these laws is vitally essential to the organization because any breach of them will have a serious impact not only on the business's financial well-being but also on its reputation.

\section{SUMMARY AND CONCLUSIONS}

The increasing prevalence of globalization is driven by a number of factors, including shortage of talent in developed countries, availability of low cost labor and growing consumers in developing countries, and technological progress. Despite the current economic downturn and unemployment, most developed countries, including United States, Germany and Japan will face long term talent shortages mainly due to ageing and retirement of baby boomers. There are more workers retiring than entering the labor force in these countries. By 2020, for every five retiring workers, only four new workers will join the labor force in most developed countries. The shrinkage of talent will be more than compensated by growing number of professional talent produced in emerging nations, yet the global supply of talent is short of its long-term demand, and the gap is a challenge for employers everywhere. The shortage between the demand and supply of talents is likely to continue to increase, notably for highly skilled professionals. The demand for talented people is increasing from developed and developing countries alike.

Only the multinational enterprises that will be willing to adapt their human resource practices to the changing global labor market conditions will be able to attract, develop and retain high performing employees, and will likely survive, and succeed in the global competition. Management of culturally diverse and geographically dispersed workforce is a key goal of global human resources. It is also critical that the 
businesses not only familiarize with local ways of doing business, and understand needs of the local consumers, but also develop a global mindset among their employees. Human resources must play roles and responsibilities in leading the organization towards openness to cultural diversity.

The human resources need to focus on organizations 'long-term objectives and on futureoriented plans. Instead of focusing exclusively on internal human resource issues, human resource departments need to take a balanced and broader approach. HR departments of global companies must assemble data on factors, such as employees, attrition and hiring, compensation and benefits, ethnic, gender, cultural, and nationality distributions, and load into data warehouses and data marts. By applying advanced analytical techniques on the data, human resource professional will get business insight, predict changes, and make informed decisions at operational and strategic levels. The human resource professional accesses current and anticipates future skills shortages through strategic skills planning. Global organizations not only need to a networked, collaborative and open to culturally diverse workforce, but also consists of high talent.

\section{REFERENCES}

1. Adler, N. J. (1997) International Dimensions of Organizational Behavior, 3rd edition. Cincinnati: South-Western College Publishing.

2. Adler, N. J. and Ghadar, F (1990) _Strategic Human Resource Management: A Global Perspective', in Pieper, R. (ed.) Human Resource Management in International Comparison. Berlin: de Gruyter

3. Hamel, G. and Prahalad, C. K. (1994) Competing for the Future. Boston Mass.: Harvard Business School Press

4. Hutchinson, S. and Purcell, J. (2003) Bringing policies to life: the vital role of front line managers in people management. Executive Briefing',

5. London: Chartered Institute of Personnel and Development

6. Tung, R. L. and Punnett, B. J. (1993) The Relationship of Staffing Practices to Organizational Level Measures of Performance, Personnel Psychology, 46: 27-48

7. Ulrich, Dave (1996) Human Resource Champions-The next agenda for adding value and delivering results. Boston, Mass.: Harvard Business School Press.

8. World Economic Forum (2011)_Global Talent Risk - Seven Responses. 